\title{
Tingkat Pengetahuan dan Persepsi Pada Siswa Terkait Larangan Merokok di SMP Negeri 18 Surakarta
}

\section{Level of Knowledge and Perception in Students Related to the Prohibitin of Smoking in Junior High School 18 Surakarta}

\author{
Indah Istyarini ${ }^{1}$, Iik Sartika ${ }^{2}$ \\ Program Studi Kesehatan Masyarakat Universitas Veteran Bangun Nusantara Sukoharjo \\ Email : indah.istya14@gmail.com
}

\begin{abstract}
Knowledge is an important domain in forming someone's actions. Perception is someone who receives stimulation, which is associated with an experience that has been done, which ultimately produces an understanding. Non-smoking area is an area that is declared prohibited for smoking activities, one of the example is a place for teaching and learning process. Public smoking bans can protect a person from the dangers of being passive smokers and reduce among teenagers for being smokers. The purpose of this study is to determine the level of knowledge and perceptions of students related to smoking bans in SMP Negeri 18 Surakarta. Researchers used a descriptive qualitative research method and the research subjects are 10 student from grade IX. The results of the study are that the older the students, the more they assume that the smoking ban is reasonable. Students' knowledge related to smoking bans in schools is appropriate because students know and understand the smoking bans written in school rules. Students' perceptions regarding smoking bans are very good, because smoking in schools is not recommended, smoking can damage organs and are very dangerous to the human body and can cause illness to death. The example of the policy regarding smoking bans is that the school has established a No Smoking Area entire of the school environment that can be seen clearly by all school residents.
\end{abstract}

Keywords : Knowledge, Perception, Prohibition of Smoking

\begin{abstract}
ABSTRAK
Pengetahuan merupakan domain penting dalam membentuk tindakan seseorang. Persepsi adalah seseorang yang menerima stimulasi, dikaitkan dengan pengalaman yang pernah dilakukan, yang menghasilkan suatu pemahaman. Kawasan Tanpa Rokok adalah area yang dinyatakan dilarang untuk kegiatan merokok, salah satunya adalah tempat proses belajar mengajar. Larangan merokok dapat melindungi seseorang dari bahaya menjadi perokok pasif dan mengurangi perokok pemula dari kalangan remaja. Tujuan penelitian untuk mengetahui tingkat pengetahuan dan persepsi pada siswa terkait larangan merokok di SMP Negeri 18 Surakarta. Peneliti menggunakan metode penelitian deskriptif kualitatif, dengan subyek penelitian 10 siswa kelas IX. Hasil penelitian adalah semakin tua umur siswa semakin menganggap bahwa larangan merokok tersebut wajar. Pengetahuan siswa terkait larangan merokok di sekolah adalah baik karena siswa tahu dan memahami larangan merokok yang tertulis di tata tertib sekolah. Persepsi siswa terkait larangan merokok adalah sangat bagus, karena merokok di sekolah tidak dianjurkan, merokok dapat membahayakan tubuh hingga kematian. Kebijakan terkait larangan merokok adalah pihak sekolah sudah menetapkan Kawasan Tanpa Rokok merata di seluruh lingkungan sekolah yang dapat dilihat jelas oleh seluruh warga sekolah.
\end{abstract}


Kata kunci: Pengetahuan, Persepsi, Larangan Merokok

\section{PENDAHULUAN}

Kemajuan suatu daerah dapat dilihat dari pembangunan suatu bangsa. Salah satu indikator keberhasilannya dapat dilihat dari aspek kesehatan. Tujuan pembangunan kesehatan terdapat dalam Undang-undang nomor 36 tahun 2009 tentang kesehatan. Pemerintah selaku penyelenggara Negara berkewajiban untuk menyelenggarakan upaya kesehatan, salah satu upaya yang harus dilakukan yaitu pengamanan yang mengandung zat adiktif terutama rokok.

Pengamanan zat yang mengandung zat adiktif tertuang dalam Undang-undang nomor 36 tahun 2009 pasal 113 ayat (1) yang berbunyi "Pengamanan penggunaan bahan yang mengandung zat adiktif diarahkan agar tidak mengganggu, dan membahayakan kesehatan perorangan, keluarga, masyarakat, dan lingkungan." Indonesia telah mengatur mengenai larangan merokok di tempat umum yang tercantum dalam Undang-undang nomor 32 tahun 2010, tempat yang dimaksud antara lain tempat umum, tempat kerja, tempat pelayanan kesehatan, arena kegiatan anak-anak, tempat ibadah, angkutan umum, dan tempat proses belajar mengajar (sekolah). Peraturan Pemerintah nomor 109 tahun 2012 tentang Pengamanan Bahan yang Mengandung Zat Adiktif Berupa Produk Tembakau Bagi Kesehatan juga mewajibkan Pemerintah Daerah untuk menetapkan Kawasan Tanpa Rokok di wilayahnya masing-masing melalui Peraturan Daerah (Perpres, 2012).

Sekolah memiliki Kebijakan Peraturan mengenai Kawasan Tanpa Rokok (KTR) yang mengacu pada Peraturan Menteri Pendidikan dan Kebudayaan Republik Indonesia nomor 64 Tahun 2015 tentang Kawasan Tanpa Rokok di lingkungan sekolah yang bertujuan untuk menciptakan lingkungan sekolah yang bersih, sehat, dan bebas rokok (Permendikbud, 2015). Peraturan Menteri Pendidikan dan Kebudayaan Republik Indonesia nomor 64 tahun 2015 Pasal 7 ayat (3) menyebutkan, "Bagi siswa yang kedapatan merokok di lingkungan sekolah maupun luar sekolah wajib mendapatkan pembinaan dari sekolah, sesuai dengan tata tertib yang berlaku."

Kota Surakarta telah membuat peraturan yang tercantum dalam Peraturan Walikota Surakarta nomor 13 tahun 2010 tentang Kawasan Tanpa Rokok dan Kawasan Terbatas Rokok. Pada Bab II Pasal 3 (2, a) berbunyi "Tempat proses belajar mengajar sebagaimana dimaksud dalam Pasal 2 ayat (2) huruf b meliputi tempat pendidikan formal yang berbentuk : SD / MI / yang sederajat; SMP / MTs / yang sederajar; SMA / MA / SMK /yang sederajat; Perguruan Tinggi; tempat pendidikan formal lainnya." (Perwali, 2010).

Berdasarkan hasil Riset Kesehatan Dasar (Riskesdas), prevalensi merokok pada populasi usia 10-18 tahun di Indonesia tahun 2013 sebesar 7,2\%, meningkat di tahun 2018 menjadi 9,1\%, diharapkan pada tahun 2019 bisa menurun sebesar 5,4\%. Prevalensi (\%) perokok usia $\geq 10$ tahun di Provinsi Jawa Tengah sebesar 28,2\% sedangkan tahun 2018 meningkat sebesar 28,5\% (Riskesdas, 2018). Menurut laporan Global Youth Tobacco Survey tahun 2014, secara keseluruhan perokok remaja usia 13-15 tahun mulai merokok di usia 12-13 tahun (43,2\%) dan sebanyak 11,4\% mulai merokok pada usia 14-15 tahun.

Kebijakan pemerintah dalam pelayanan publik khususnya dalam bidang kesehatan salah satunya adalah diberlakukannya larangan merokok dengan adanya kebijakan kawasan tanpa rokok. Penerapan 100\% kawasan tanpa asap rokok sangat penting untuk dapat menyelamatkan kehidupan. Larangan merokok di kawasan tanpa rokok akan memberikan dampak kesehatan bagi perokok maupun bukan perokok. Larangan ini akan mengurangi paparan bukan perokok pada asap tembakau lingkungan dan mengurangi konsumsi rokok diantara para perokok (Elsa Maharani, 2015). 
Sekolah Menengah Pertama (SMP) Negeri di wilayah Surakarta secara umum mendukung kebijakan kawasan tanpa rokok, salah satunya adalah SMP Negeri 18 Surakarta. Pada SMP Negeri 18 Surakarta sudah ada larangan yang jelas bagi siswa yang merokok dan sanksi yang didapat jika ketahuan merokok di lingkungan sekolah. Berdasarkan studi dokumen yang peneliti lakukan yaitu dari catatan pelanggaran tata tertib yang dilakukan siswa terutama terkait merokok di lingkungan sekolah pada bulan Juli 2019, di dapatkan hasil bahwa pada tahun 2017, terdapat 11 siswa kedapatan merokok di area lingkungan sekolah, pada tahun 2018 terdapat 6 siswa dan di tahun 2019 ditemukan 9 siswa. Hal ini menunjukkan meskipun sudah ada larangan merokok di sekolah, masih terdapat siswa yang kedapatan merokok di sekolah. Tujuan peneliti melakukan penelitian di SMP Negeri 18 Surakarta yaitu ingin mengetahui sejauh mana tingkat pengetahuan dan persepsi siswa terkait larangan merokok di sekolah.

\section{METODE}

Penelitian ini menggunakan metode penelitian deskriptif kualitatif. Penelitian tentang Tingkat Pengetahuan dan Persepsi Pada Siswa Terkait Larangan Merokok di Sekolah ini dilaksanakan dengan tahapan-tahapan. Penelitian ini dimulai dengan pengajuan judul penelitian sampai penelitian ini dilaksanakan. Semua rangkaian penelitian ini dimulai pada bulan Maret sampai Agustus 2019 di SMP Negeri 18 Surakarta.

Subjek penelitian ini adalah siswa kelas IX, guru dan kepala sekolah SMP Negeri 18 Surakarta yang merupakan informan utama, sedangkan obyek penelitian ini adalah tentang pengetahuan, persepsi dan larangan merokok di SMP Negeri 18 Surakarta.

Peneliti menggunakan catatan hasil wawancara dan hasil pengamatan langsung di lapangan sebagai sumber data primer penelitiannya dan menggunakan catatan atau dokumen yang sudah ada di sekolah sebagai sumber data sekunder penelitiannya. Peneliti menggunakan teknik pemeriksaan keabsahan data yaitu triangulasi sumber, triangulasi metode dan triangulasi teori. Metode pengumpulan data yang digunakan peneliti adalah observasi, wawancara mendalam (Indepth Interview) dan studi dokumen.

Analisis data dalam penelitian kualitatif, dilakukan pada saat pengumpulan data berlangsung, dan setelah selesai pengumpulan data periode tertentu. Peneliti akan melanjutkan pertanyaan lagi apabila jawaban yang diwawancarai setelah di analisis terasa belum memuaskan, sampai tahap tertentu, diperoleh data yang dianggap kredibel (Sugiyono, 2016).

\section{HASIL DAN PEMBAHASAN}

Berikut daftar siswa kelas IX SMP Negeri 18 Surakarta yang menjadi responden dalam penelitian ini, yaitu sebagai berikut :

Tabel 4. Siswa Kelas IX (Responden Penelitian)

\begin{tabular}{ccccc}
\hline No. & Nama (Inisial) & Jenis Kelamin & Umur & Alamat \\
\hline 1 & DVM & $\mathrm{L}$ & $15 \mathrm{th}$ & Gebang \\
2 & KADT & $\mathrm{L}$ & $14 \mathrm{th}$ & Wonorejo \\
3 & LPA & $\mathrm{P}$ & $14 \mathrm{th}$ & Plesungan \\
4 & TIP & $\mathrm{P}$ & $16 \mathrm{th}$ & Punggawan \\
5 & IGAP & $\mathrm{L}$ & $16 \mathrm{th}$ & Mojosongo \\
6 & AA & $\mathrm{L}$ & $15 \mathrm{th}$ & Gebang \\
7 & ANS & $\mathrm{P}$ & $14 \mathrm{th}$ & Njengglong \\
8 & INK & $\mathrm{L}$ & $14 \mathrm{th}$ & Mojosongo \\
9 & ATPW & $\mathrm{P}$ & $13 \mathrm{th}$ & Banyubiru \\
10 & TAK & $\mathrm{L}$ & $14 \mathrm{th}$ & Jetak \\
\hline \multicolumn{5}{c}{ Sumber : data primer yang diolah peneliti (2019) }
\end{tabular}

Hasil penelitian mengenai karakteristik siswa terutama dalam hal umur, dari 10 siswa yang menjadi responden penelitian di dapatkan hasil siswa dengan rentang usia 13-16 
tahun, yang terdiri dari usia 13 tahun sebanyak 1 siswa, usia 14 tahun sebanyak 5 siswa, usia 15 tahun sebanyak 2 siswa dan usia 16 tahun sebanyak 2 siswa. Berdasarkan hasil tersebut, dari 10 siswa yang menjadi responden, diketahui bahwa umur terendah adalah 13 tahun, umur tertinggi 16 tahun dan rata-rata umur responden adalah 14 tahun. Hasil peneitian dari 10 siswa yang menjadi responden terdiri dari 6 orang siswa laki-laki dan 4 orang siswa perempuan.

Seluruh siswa yang diteliti sebenarnya mengetahui tentang larangan merokok yang ada di sekolah dan mereka mengatahui akibat atau sanksi yang akan siswa terima ketika siswa ketahuan merokok di lingkungan sekolah karena seluruh larangan dan sanksi yang di dapat sudah tertera di tata tertib sekolah.

Menurut persepsi siswa, larangan merokok tersebut sudah baik adanya karena sudah sepantasnya sekolah memberi larangan dan sanksi terkait merokok.

Hasil penelitian dengan cara observasi menunjukkan bahwa SMP Negeri 18 Surakarta telah menetapkan lingkungannya sebagai area dilarang merokok atau Kawasan Tanpa Rokok (KTR). Berdasarkan hasil observasi, ditemukan daerah yang dinyatakan dilarang merokok adalah ruang guru, mushola, ruang komputer, luar ruang kelas, laboratorium di lingkungan SMP Negeri 18 Surakarta.

Secara umum, kebijakan tentang larangan merokok berlaku untuk semua warga sekolah yang berada di lingkungan SMP Negeri 18 Surakarta, mulai dari kepala sekolah, guru, karyawan dan siswa. Berdasarkan hasil indeph nterview dengan kepala sekolah, secara umum larangan merokok sudah ada di tata tertib sekolah. Hal ini sesuai dengan jawaban kepala sekolah yaitu:

"larangan merokok sudah jelas ada di tata tertib sekolah, lewat banner juga ada. Kebijakan larangan merokok dari dinas pendidikan dan dari walikota juga sudah ada (bahkan di gedung walikota dilarang merokok), tapi saya lupa pasalnya berapa. Kebijakan larangan merokok ini seperti mata rantai, dari walikota lalu dinas pendidikan, kemudian dilakukan sosialisasi ke sekolah-sekolah".

Sosialisasi terkait larangan merokok di SMP Negeri 18 Surakarta sudah dilaksanakan oleh guru maupun bagian kesiswaan. Hal ini sesuai dengan jawaban bagian kesiswaan saat dilakukan indeph interview yaitu

"sosialisasi dilaksanakan secara berkelanjutan terus menerus, dilakukan secara rutin, kalau nggak gitu anak-anak tidak jera. Setiap ada kesempatan pasti dilakukan, saat mengajarpun guru selalu menyampaikan di awal sebelum memulai pelajaran, pada saat upacara bendera. Tujuannya agar anak bisa terlepas dari rokok. Sebenarnya sudah sering diadakan seminar tenatng bahaya merokok dari dinas ke sekolah, atau kadang dari pihak sekolah mengirim guru ke dinas, kemudian guru mensosialisasikan ke sekolah pada saat masa pengenalan lingkungan sekolah”.

Penelitian ini bertujuan ingin mengetahui sejauh mana tingkat pengetahuan dan persepsi siswa terkait larangan merokok di SMP Negeri 18 Surakarta. Peneliti melakukan observasi, indeph interview yang sudah dibuat beberapa pertanyaan oleh peneliti yang kemudian ditanyakan atau diberikan kepada responden/ informan untuk dijawab, serta studi dokumentasi berdasarkan data/ catatan yang ada di sekolah. Penelitian ini dilakukan pada tanggal 19-26 Juli 2019.

Faktor yang diteliti untuk mengetahui tingkat pengetahuan seseorang terutama siswa pada penelitian ini adalah jika dari faktor internal yaitu umur, jenis kelamin dan pekerjaan 
orang tua sedangkan faktor eksternal yang diteliti adalah sosial budaya, bagaimana budaya dilingkungan sekitar siswa yang menjadi subyek penelitian.

Hasil penelitian mengenai karakteristik siswa terutama dalam hal umur, dari 10 siswa yang menjadi responden penelitian di dapatkan hasil siswa dengan rentang usia 13-16 tahun, yang terdiri dari usia 13 tahun sebanyak 1 siswa, usia 14 tahun sebanyak 5 siswa, usia 15 tahun sebanyak 2 siswa dan usia 16 tahun sebanyak 2 siswa. Berdasarkan hasil tersebut, dari 10 siswa yang menjadi responden, diketahui bahwa umur terendah adalah 13 tahun, umur tertinggi 16 tahun dan rata-rata umur responden adalah 14 tahun. Hal ini sesuai dengan laporan Global Youth Tobacco Survey tahun 2014 yaitu secara keseluruhan perokok remaja usia 13-15 tahun mulai merokok di usia 12-13 tahun $(43,2 \%)$ dan sebanyak $11,4 \%$ mulai merokok pada usia 14-15 tahun.

Seperti yang dipaparkan oleh responden "KADT" saat peneliti menanyakan apa alasannya ingin merokok waktu pertama kalinya yaitu :

"ya karena pengen mbak, ada orang lewat pas ngerokok, kok kayakke enak, orang itu ngebuang rokoknya, terus aku ambil, aku coba, kan belum mati itu apinya, masih ada sisa rokoknya sedikit”.

Menurut Nursalam (2011), beberapa faktor yang mempengaruhi pengetahuan seseorang, yaitu umur (semakin cukup umur tingkat kematangan dan kekuatan seseorang akan lebih matang dalam berpikir), jenis kelamin (suatu sifat yang melekat pada kaum lakilaki maupun perempuan yang dikontruksikan secara sosial maupun kultural), dan sosial budaya (semakin tinggi tingkat pendidikan dan status sosial seseorang maka tingkat pengetahuannya akan semakin tinggi).

Berdasarkan hasil indeph interview dengan siswa kelas IX yang menjadi responden penelitian, mereka mengakatan sebagian besar siswa yang pernah ketahuan merokok di sekolah adalah siswa laki-laki, seperti ungkapan dari responden "TIP" yang mengatakan:

"kebayakan yang ketahuan itu laki-laki mbak, perempuan juga ada tapi nggak sebanyak laki-laki, paling Cuma 1 atau 2 aja kalau perempuan”.

Dilihat dari sisi sosial budaya, mayoritas yang ada di sekitar siswa (di rumah) terkait larangan merokok termasuk kurang, karena setelah ditanya ternyata banyak orang di sekitar siswa tersebut adalah perokok aktif dan ada beberapa orang tua dari mereka yang juga merupakan perokok. Kurangnya hukuman atau sanksi yang ada di rumah menyebabkan anak merasa bebas untuk merokok dan ada orang tua yang membiarkan anak merokok di sekolah karena orangtua merasa jengkel pada anak yang tidak bisa diberitahu.

Berdasarkan hasil penelitian dapat disimpulkan bahwa karakteristik siswa mempunyai pengaruh besar dalam menentukan pengetahuan dan persepsi terhadap sesuatu hal, semakin dewasa umur seseorang maka tingkat pengetahuan dan persepsinya semakin terarah, mereka mengetahui apa dampak dari sesuatu hal yang mereka lakukan. Prevalensi merokok pada remaja masih dominan oleh remaja laki-laki, jenis kelamin juga mempengaruhi pengetahuan dan persepsi, persepsi terhadap merokok dan larangannya, laki-laki masih menganggap bahwa larangan tersebut biasa aja, mereka akan tetap merokok secara diam-diam sedangkan perempuan menganggap bahwa larangan merokok itu perlu ditingkatkan karena masih banyak siswa yang kedapatan merokok di sekolah. Budaya yang ada disekitar siswa termasuk kurang, perilaku merokok sendiri banyak timbul karena pengaruh teman sebaya dan orang tua mereka, siswa menganggap jika dirumah hukuman yang didapatkan tidak terlalu berat, jadi mereka merasa masih bebas untuk merokok selagi tidak ketahuan, di sekolahpun, selama orang tua belum pernah dipanggil dan mereka 
merokok secara aman tanpa ketahuan guru, para siswa akan tetap melakukan kebiasaan merokok tersebut.

Berdasarkan hasil penelitian mengenai sejauh mana tingkat pengetahuan siswa terkait larangan merokok di sekolah di dapatkan hasil bahwa keseluruhan siswa yang menjadi responden mengetahui tentang larangan merokok di sekolah karena keseluruhan tertera di halaman sekolah yaitu adanya Kawasan Tanpa Rokok (KTR) dan tata tertib sekolah, di tata tertib ada terkait larangan merokok dan sanksi yang di dapat jika ada siswa yang ketahuan merokok. Seluruh siswa mengetahui konsekuensi yang di dapat jika ada siswa yang ketahuan merokok yaitu jika ketahuan sekali akan mendapatkan teguran, ketahuan dua kali akan ditegur lagi ditambah orang tua siswa diminta menghadap guru BP.

Peneliti menanyakan hal serupa ke bagian kesiswaan yaitu mengenai adakah larangan merokok atau Kawasan Tanpa Rokok di lingkungan SMP Negeri 18 Surakarta dan apa saja sanksi yang akan diterima jika ada siswa yang ketahuan merokok di lingkungan sekolah, kemudian guru menjawab,

"untuk larangan merokok jelas ada, yang bisa dilihat langsung adalah adanya Kawasan Tanpa Rokok (KTR) yang sudah banyak di pasang di lingkungan sekolah, ada di ruang guru, halaman sekolah dan di tempat-tempat strategis yang bisa di lihat oleh semua warga sekolah. Peraturan tertulis tentang larangan merokok sudah ada di tata tertib sekolah beserta sanksi yang akan di dapat, dipaparkan oleh guru tersebut mengenai sanksi yang didapat adalah jika siswa ketahuan 1 kali akan di tegur dan di minta membuat surat pernyataan bahwa tidak akan mengulangi merokok di sekolah lagi, jika ketahuan untuk ke 2 kalinya akan dilakukan pemanggilan orang tua, jika ketahuan untuk ke 3 kalinya dan siswa tidak mau berhenti merokok ya akhirnya akan dikeluarkan dari sekolah. Sejauh ini belum ada siswa yang sampai di keluarkan dari sekolah karena biasanya 2 kali ketahuan lalu mereka jera."

Berdasarkan hasil penelitian, tingkat pengetahuan siswa terkait larangan merokok disekolah adalah keseluruhan siswa sudah tahu ada larangan merokok di lingkungan sekolah, mereka juga memahami apa saja konsekuensi atau dampak yang didapatkan apabila sampai ketahuan merokok, pihak sekolah selalu mengaplikasikan hukuman yang ada di tata tertib dengan fenomena atau kejadian yang ada, jika ada siswa yang ketahuan merokok meraka langsung mendapatkan poin dan poin tersebut sudah dicatat di ruang BP, pihak sekolah juga menganalisa berapa poin yang sudah didapat oleh siswa atas ketidak sesuaian sikap siswa dengan tata tertib yang ada selama jam pembelajaran, sudah ada peraturan terkait poin-poin yang didapat, siswa melakukan evaluasi terhadap larangan merokok di sekolah, menurut pengetahuan siswa, larangan merokok ini sudah dipasang secara menyeluruh di lingkungan sekolah dan hukumannya sudah ada jelas di dalam tata tertib sekolah. Sosialisasi yang diberikan oleh pihak sekolah juga tidak kurang-kurang, perlu dilakukan pemantauan yang lebih ketat terhadap larangan merokok dan sanksi yang didapatkan.

Hasil penelitian mengenai bagaimana persepsi siswa terkait larangan merokok di sekolah, jawaban dari hasil wawancara adalah menurut mereka larangan merokok tersebut sangat bagus, karena merokok di sekolah tidak dianjurkan, merokok dapat merusak organ dan sangat membahayakan tubuh serta dapat menyebabkan penyakit hingga kematian. Namun ada juga yang berpendapat bahwa wajar jika di sekolah ada larangan merokok karena masa-masa sekolah butuh pengetahuan dan pengarahan tentang rokok.

Sesuai dengan teori dari Sarlito W. Sarwono (2009) yang berpendapat bahwa persepsi secara umum merupakan proses perolehan, penafsiran, pemilihan dan pengaturan informasi indrawi. Persepsi mengandung suatu proses dalam diri untuk mengetahui dan 
mengevaluasi sejauh mana kita mengetahui oranglain. Proses ini menuntut kepekaan dalam diri seseorang terhadap lingkungan sekitar, cara pandang akan menentukan kesan yang dihasilkan dari proses persepsi.

Selanjutnya mengenai sosialisasi terkait larangan merokok di sekolah, tanggapan dari para siswa adalah perlu sekali dan penting agar siswa lebih mengerti betapa bahayanya merokok dan tidak merokok lagi, sebenarnya tiap hampir seminggu sekali pasti ada sosialisasi dari sekolah.

Kedekatan anak muda terhadap rokok saat ini sudah sangat tinggi. Sifat yang mudah terpengaruh dan terbawa arus menjadikan anak muda mudah dekat dengan rokok. Atas dasar ini, remaja dan anak-anak harus mendapatkan perlindungan dari pemasaran rokok yang agresif. Lisda Sundari, Ketua Lentera Anak Indonesia mengatakan, industri rokok saat ini banyak membombardir remaja dengan iklan rokok yang memengaruhi pola pikir remaja. Mereka memberikan bentuk bahwa merokok merupakan satu tindakan positif.

Bahaya rokok akan lebih berdampak pada anak-anak karena semakin muda seseorang mulai merokok, maka dia akan semakin mudah untuk ketagihan dan sulit untuk berhenti merokok. Menurut Lisda, anak-anak yang saat ini sudah mulai merokok sejak usia 10 tahun akan menjadi generasi yang sakit-sakitan 15 tahun kemudian maka dari itu harus ada upaya nyata untuk melindungi anak-anak dari bahaya rokok.

Kebijakan terkait larangan merokok di SMP Negeri 18 Surakarta jika peneliti amati sebenarnya sudah cukup jelas aturan dan hukuman yang didapatkan jika ada siswa yang ketahuan merokok. Para siswa saat ditanya, keseluruhan mengetahui bahwa ada larangan merokok tertulis di tata tertib dan ada tulisan Kawasan Tanpa Rokok di lingkungan sekolah.

Larangan merokok ini belum berjalan secara maksimal karena masih banyak ditemukan siswa yang merokok di lingkungan SMP Negeri 18 Surakarta. Selain itu, salah satu penyebab kurangnya kepatuhan terhadap larangan merokok tersebut adalah karena masih ada siswa yang menyepelekan sanksi yang didapat jika ketahuan merokok di lingkungan SMP Negeri 18 Surakarta.

Berdasarkan tingkat kebijakan, yang terdiri dari kebijakan makro, kebijakan meso dan kebijakan mikro. Menurut hasil penelitian dan latar belakang penelitian, didapatkan hasil bahwa kebijakan makro terdiri dari Undang-undang Republik Indonesia Nomor 36 tahun 2009 tentang Kesehatan pasal 115 yang mengatur tentang Kawasan Tanpa Rokok, salah satunya adalah Tempat Proses Belajar Mengajar dan Undang-undang Republik Indonesia Nomor 32 tahun 2010 tentang Larangan Merokok. Kebijakan Meso terdiri dari Peraturan Pemerintah Nomor 109 tahun 2012 tentang Pengamanan Bahan yang Mengandung Zat Adiktif Berupa Produk Tembakau Bagi Kesehatan, Peraturan Menteri Pendidikan dan Kebudayaan (Permendikbud) Nomor 63 tahun 2015 tentang Kawasan Tanpa Rokok di Lingkungan Sekolah dan Peraturan Walikota (Perwali) Kota Surakarta Nomor 13 tahun 2010 tentang Kawasan Tanpa Rokok dan Kawasan Terbatas Merokok, sedangkan kebijakan mikro dari penelitian ini adalah Tata Tertib pada siswa SMP Negeri 18 Surakarta.

Masukan untuk SMP Negeri 18 Surakarta, selain sosialisasi saat apel upacara yang selama ini hanya dari pihak sekolah saja, mungkin lebih baik ada campur tangan dari pihak luar, misal kemarin sudah ada sosialisasi/penyuluhan yang melibatkan pihak kepolisian, bisa ditambah pula penyuluhan dan/atau sosialisasi dari dinas kesehatan atau puskesmas setempat, diharapkan dengan adanya penyuluhan dari berbagai pihak terkait, jumlah remaja perokok di SMP Negeri 18 Surakarta bisa berkurang. 


\section{KESIMPULAN}

Dari hasil penelitian tentang tingkat pengetahuan dan persepsi pada siswa terkait larangan merokok di SMP Negeri 18 Surakarta yang dilakukan oleh peneliti pada bulan Maret - Agustus 2019 di SMP Negeri 18 Surakarta dengan dibandingkan pada tinjauan teori tentang topik tersebut di atas, didapatkan kesimpulan bahwa:

1. Karakteristik siswa mengenai larangan merokok di sekolah adalah berbeda-beda, siswa dengan usia mulai dari 13 - 16 tahun termasuk dalam remaja awal, semakin tua umur siswa semakin menganggap bahwa larangan tersebut wajar. Faktor kurangnya perhatian dari orang tua juga menjadi salah satu alasan siswa tersebut menyepelekan aturan terkait larangan merokok di sekolah.

2. Tingkat pengetahuan siswa terkait larangan merokok di SMP Negeri 18 Surakarta adalah secara keseluruhan siswa sudah mengetahui tentang larangan merokok di sekolah karena tertulis di tata tertib sekolah lengkap dengan sanksi atau hukuman yang di terima jika ketahuan merokok.

3. Persepsi siswa tentang larangan merokok di SMP Negeri 18 Surakarta adalah mereka berpendapat bahwa larangan merokok tersebut sangat bagus, karena merokok di sekolah tidak dianjurkan, merokok dapat merusak organ dan sangat membahayakan tubuh serta dapat menyebabkan penyakit hingga kematian. Namun ada juga yang berpendapat bahwa wajar jika di sekolah ada larangan merokok karena masa-masa sekolah butuh pengetahuan dan pengarahan tentang rokok.

4. Kebijakan larangan merokok di SMP Negeri 18 Surakarta adalah pihak sekolah sudah menetapkan Kawasan Tanpa Rokok (KTR) merata di seluruh lingkungan sekolah yang dapat dilihat jelas oleh seluruh warga sekolah. Larangan Merokok juga tertulis di tata tertib sekolah lengkap dengan hukuman atau sanksi yang di dapat.

\section{SARAN}

Pihak sekolah agar lebih meningkatkan hukuman terkait larangan merokok di lingkungan sekolah dan membuat larangan merokok di warung-warung sekitar SMP Negeri 18 Surakarta. Siswa sebagai sasaran penelitian agar lebih mendisiplinkan diri terhadap tata tertib sekolah terutama terkait larangan merokok di SMP Negeri 18 Surakarta. Bagi Universitas Veteran Bangun Nusantara Sukoharjo, diharapkan bisa menjadi referensi perpustakaan Fakultas Kesehatan Masyarakat dan masukan bagi mahasiswa yang sedang mempelajari tentang penelitian yang serupa. Bagi peneliti selanjutnya yang ingin melakukan penelitian yang serupa, masih terbuka kesempatan dan hal yang bisa dikupas dan diteliti lebih jauh dan lebih dalam lagi. Harapannya dengan adanya penelitian ini mampu menjadi dasar bagi penelitian selanjutnya untuk mengembangkan temuan-temuan baru terkait larangan merokok.

\section{DAFTAR PUSTAKA}
Elsa Maharani, dkk. 2015. "Studi Implementasi Kebijakan Larangan Merokok di Universitas Andalas Tahun 2012”. (Online). (http://jurnal.fkm.unand.ac.id/index.php/jkma/article/view/212/206.diakses pada tanggal 10 April 2019)

Peraturan Menteri Pendidikan dan Kebudayaan Republik Indonesia Nomor 64 tahun 2015 tentang Kawasan Tanpa Rokok d Lingkungan Sekolah

Nursalam. 2011. Konsep dan penerapan metodologi penelitian ilmu keperawatan. Jakarta : Salemba Medika 
Peraturan Pemerintah Nomor 109 tahun 2012 tentang Pengamanan Bahan yang Mengandung Zat Adiktif Berupa Produk Tembakau Bagi Kesehatan

Peraturan Walikota Surakarta Nomor 13 tahun 2010 tentang Kawasan Tanpa Rokok dan Kawasan Terbatas Rokok

Riset Kesehatan Dasar (Riskesdas). 2018. Badan Penelitian dan Pengembangan Kesehatan Kementrian RI tahun 2018. http://www.depkes.go.id/resources/download/infoterkini/materi rakorpop 2018/Hasil\%20Ri skesdas\%202018.pdf - Diakses Mei 2019.

Sugiyono. 2016. Metode Penelitian Kuantitatif, Kualitatif dan R\&D. Bandung: PT Alfabet

Tobacco Control Support Centre-IAKMI, Kementerian Kesehatan. 2015. Bunga Rampai Fakta Tembakau dan Permasalahannya di Indonesia Tahun 2014. Jakarta: Tobacco Control Support Centre-IAKMI

Tata Tertib Siswa No. 420/379/VII/2019 SMP Negeri 18 Surakarta tahun 2019

Undang-undang Republik Indonesia Nomor 32 tahun 2010 tentang Larangan Merokok

Undang-undang Republik Indonesia Nomor 36 tahun 2009 tentang Kesehatan 